\title{
PODEJŚCIE KLASTROWE DO TWORZENIA DESTYNACJI TURYSTYCZNYCH W PRZYGRANICZNYCH OBWODACH ZACHODNIEJ UKRAINY
}

\author{
Vasyl Kyfyaka, Olexander Kyfyak \\ ${ }^{a}$ Czerniowiecki Instytut Handlowo-Ekonomiczny, Kijowski Narodowy Uniwersytet Handlu i Ekonomii, Katedra Zarządzania, \\ Ekonomii Międzynarodowej i Turystyki; e-mail: tourbuc@ukr.net \\ ${ }^{\mathrm{b}}$ Czerniowiecki Uniwersytet Narodowy im. Jurija Fedkowycza, Wydział Ekonomii, Katedra Marketingu, Innowacji i Rozwoju \\ Regionalnego; e-mail: o.kyfyak@chnu.edu.ua
}

\begin{abstract}
ABSTRAKT
Niniejszy artykuł dotyczy przygranicznych obwodów zachodniej Ukrainy. Tereny te odznaczają się dużą liczbą naturalnych zasobów rekreacyjnych, zabytków historii, kultury i architektury, rozbudowaną infrastrukturą transportową oraz silnymi więziami etnicznymi z regionami znajdującymi się w krajach sąsiedzkich. Są to miejsca, w których istnieją duże możliwości rozwoju ruchu turystycznego o charakterze transgranicznym. W celu osiągnięcia postawionego sobie celu badawczego autorzy przeanalizowali doświadczenia innych krajów, w szczególności związane z procesami tworzenia klastrów w Rumunii i Polsce oraz zarządzania nimi, co pomogło w identyfikacji etapów tworzenia destynacji turystycznej, opartego na podejściu klastrowym. Porównanie działania wcześniej utworzonych klastrów turystycznych na Ukrainie i za granicą pomogło w sporządzeniu listy głównych struktur biznesowych, które mogłyby stać się częścią klastra oraz zostać zaangażowane w kreowanie miejsc wypoczynku. Na podstawie analizy potencjału naturalnego i rekreacyjnego, jak również dziedzictwa kulturowego i historycznego obwodów przygranicznych na zachodzie Ukrainy ustalono możliwe profile regionów docelowych, a także znaczenie zainteresowania turystów oraz innych firm przy tworzeniu klastrów, które zostało potwierdzone przez badania ankietowe.
\end{abstract}

\section{SŁOWA KLUCZOWE}

klaster, podejście, obwody przygraniczne, destynacje turystyczne, tworzenie destynacji

\section{INFORMACJE O ARTYKULE}

\section{Przyjęto:}

26 listopada $2020 \mathrm{r}$.

Zaakceptowano:

11 maja $2021 \mathrm{r}$.

Opublikowano:

18 czerwca $2021 \mathrm{r}$.

\section{WSTĘP}

Regiony przygraniczne zachodniej Ukrainy, w których z powodzeniem mogą działać organizacje turystyczne wytwarzające typowe usługi oraz firmy oferujące usługi powiązane, charakteryzują się różnym podejściem do rozwoju małych i średnich przedsiębiorstw, tworzenia nowych miejsc pracy, wzrostu przychodów dla lokalnego budżetu, zapewnienia atrakcyjności inwestycyjnej itp. Ze strategicznego punktu widzenia ważne jest, by firmy działające $\mathrm{w}$ regionie, który może stać się popularnym miejscem wypoczynku, oferowały za dodatkową opłatą produkty turystyczne z usługami podstawowymi i pokrewnymi. Świadomość oraz zrozumienie potrzeby współpracy z innymi przedsiębiorstwami w przyszłej destynacji, a także przedsięwzięcia ukierunkowane na utrzymanie kontaktu z powiązany$\mathrm{mi}$ organizacjami zaangażowanymi $\mathrm{w}$ tworzenie produktu turystycznego są kluczem do zrównoważonego i nieprzerwanego działania poszczególnych firm.

Jednocześnie tworzenie miejsc wypoczynku w obwodach przygranicznych na zachodzie Ukrainy cechuje się swoistymi problemami i wymaga określenia jasnych celów, obszarów priorytetowych dla profilów rozwoju 
turystyki w przyszłych celach podróży, rozwinięcia metodologii, w której jednym z aspektów może być podejście klastrowe. Wymienione kwestie decydują o wadze niniejszych badań naukowych.

Celem artykułu jest zbadanie możliwości, jakie daje podejście klastrowe w tworzeniu miejsc wypoczynku w obwodach przygranicznych na zachodzie Ukrainy, na podstawie analizy doświadczenia innych krajów oraz określenia poszczególnych etapów podejścia do tworzenia destynacji turystycznych, w tym analizy potencjału turystycznego oraz tworzenia modelu klastrowego z uwzględnieniem lokalizacji przygranicznej.

\section{PRzegląd Literatury}

Wielu badaczy, zarówno ukraińskich, jak i zagranicznych, uważa, że skuteczne zarządzanie dostępnymi zasobami ma decydujący wpływ na rozwój danego obszaru. Kwestie rozwoju regionalnego, atrakcyjności inwestycyjnej, udostępniania zasobów, tworzenia przewagi konkurencyjnej, podziału na strefy ekonomiczne i regionalnej polityki gospodarczej kraju w nowych warunkach ekonomicznych omawiają w swoich pracach m.in. Algieri, Aquino, Succurro (2018); Beltramo, Rostagno i Bonadonna (2018); Bobrovska, Krushelnytska, Latinin, Lypovska, Dreshpak (2017); Melnik (2018); Mazaraki (2019); Oteshova i in. (2020); Stasiak (2007); Varnalius (2005).

Varnalius uważa, że potencjał zasobów danego regionu jest „główną podstawą tworzenia mechanizmu realizacji jego interesów gospodarczych" (Varnalius, 2005, s. 78). Z kolei Melnik, analizując zasoby danego obszaru, wyróżniła "siłę robocza, zasoby naturalne (wodne, gruntowe, mineralne, biologiczne, leśne), produkty, infrastrukturę, zasoby finansowe" (Melnik, 2018, s. 9). Podział ten potwierdzili Gerasymenko wraz z grupą badaczy, którzy zwrócili uwagę na potencjał zasobów naturalnych danego obszaru, obejmujący „wszystkie rodzaje dostępnych zasobów: mineralne, gruntowe, wodne, biologiczne, rekreacyjne, biosfery itp." (Gerasymenko, 2016, s. 68). W pracach wymienionych autorów zostały uwzględnione problemy teoretyczne i metodologiczne związane z wykorzystaniem zasobów w obszarze ich rozwoju i zarządzania, planowania działalności gospodarczej, wdrażania innowacji itp.

Amerykański badacz M. Porter wniósł znaczący wkład w zastosowanie podejścia klastrowego do rozwoju regionów. Definiuje on klastry jako „geograficznie skoncentrowane grupy współzależnych firm, wyspecjalizowanych dostawców, usługodawców, firm z pokrewnych branż, jak również organizacji powiązanych z ich działalnością (np. uniwersytetów, agencji standaryzacyjnych, zrzeszeń branżowych producentów) w pewnych obszarach, które ze sobą konkuruja, a jednocześnie prowadzą podobną działalność" (Porter, 2005, s. 205-206). Badacz ten opisał szczegółowo czynniki strukturalne określające intensywność konkurencji, jak również rozwój przemysłu oraz strategię konkurencyjną na różnych jego etapach. Analizując organizację czynników produkcji i ich związek z koncepcją konkurencyjności, Porter odkrył, że najbardziej konkurencyjne międzynarodowe firmy nie zostały usytuowane przypadkowo, lecz zazwyczaj są zlokalizowane w jednym konkretnym kraju lub regionie ze względu na chęć wywołania efektu synergii poprzez interakcje $\mathrm{z}$ innymi firmami.

Właśnie na takiej podstawie tworzony jest klaster - zespół firm i branż, które wzajemnie na siebie oddziałują i przyczyniają się do wzrostu swojej konkurencyjności. Jak wskazują Yalçınkaya i Güzel, „oczekuje się, iż zależności oraz powiązania klastrów turystycznych osiągną większy stopień aktywności i skomplikowania, natomiast wykorzystywanie sieci oraz płynących z nich korzyści wydaje się nieuniknione dla firm z branży" (Yalçınkaya, Güzel, 2019, s. 33).

Przedsiębiorstwa klastrowe są najbardziej wydajne. Naumanen podkreśla, iż klaster to geograficzna koncentracja lub grupa położonych blisko siebie i wzajemnie powiązanych firm z danej branży (Naumanen, 2019). Doświadczenia z różnych krajów pokazuja, że „na świecie w rejonach przygranicznych istnieje niemal trzykrotnie więcej globalnych firm zebranych w wyspecjalizowane klastry niż w innych lokalizacjach" (Naumanen, 2019, s. 5).

Badając wkład turystyki w zrównoważony rozwój gospodarczy danego regionu oraz jej integrację w strategię rozwoju regionalnego, grupa naukowców spoza Ukrainy (Bellini, Grillo, Lazzeri, Pasquinelli, 2017) przeprowadziła analizę rozwoju „,strategii inteligentnej specjalizacji”. Zidentyfikowali oni potencjalne znaczenie turystyki jako czynnika decydującego o stabilności gospodarczej regionu.

W odniesieniu do zastosowania podejścia klastrowego w turystyce ważne jest badanie przeprowadzone przez Novelli, Schmitz i Spencer (2006). W swojej pracy zatytułowanej Networks, clusters and innovations in tourism: the Great Britain experience podkreślają one, że klastry przyczyniają się do rozwoju innowacyjnych możliwości dla małych i średnich przedsiębiorstw, a także gwarantują ich konkurencyjność w środowisku turystycznym. Badaczki zaznaczyły również, że tworzenia klastrów nie powinno być postrzegane jako prosty i spontaniczny proces, wynikający z charakteru zaangażowanych w niego przedsiębiorstw, ale jako działanie niezwykle złożone, wiążące się z intensywną współpracą pomiędzy interesariuszami (Novelli, Schmitz, Spencer, 2006).

Naukowo-analityczny raport pt. The development of cross-border cooperation, opublikowany przez Instytut Badań Regionalnych im. M.I. Dolisznego Narodowej 
Akademii Nauk Ukrainy (Kravtsiv, 2015), a także studia Bennera (2017) zostały poświęcone regionalnemu oraz innowacyjnemu rozwojowi turystyki, opartemu na podejściu klastrowym. Podobne badania przeprowadzili także inni naukowcy, m.in.: Korzh i Basyuk (2017), Mikula, Matvyeyev i Tymechko (2014) oraz Odinokova (2019).

Jednocześnie wykorzystanie doświadczeń innych krajów w kształtowaniu destynacji turystycznych $\mathrm{w}$ regionach przygranicznych na podstawie podejścia klastrowego, badanie ich potencjału turystycznego, rozwijanie modelu klastra oraz różnego stosunku do problemu kreowania destynacji turystycznych pozostają kwestiami otwartymi i wymagają dalszych analiz.

\section{Metodologia BAdAŃ}

W niniejszej pracy wykorzystano następujące metody i podejścia naukowe:

- analiza i synteza klastrów turystycznych w Rumunii i Polsce, określenie potencjału naturalnego oraz rekreacyjnego wraz z dziedzictwem kulturowym i historycznym obwodów przygranicznych na zachodzie Ukrainy, co przyczyniło się do ustalenia pewnych etapów $\mathrm{w}$ tworzeniu regionów turystycznych oraz identyfikacji możliwych profilów tych miejsc;

- porównanie ustanowionej działalności klastrów turystycznych na Ukrainie oraz w krajach sąsiedzkich w celu sporządzenia listy głównych struktur biznesowych, które mogłyby stać się częścią klastra oraz zostać zaangażowane $\mathrm{w}$ tworzenie destynacji turystycznych;

- badania ankietowe przeprowadzone w celu identyfikacji zainteresowania tworzeniem klastrów turystycznych przedstawicieli branży turystycznej obwodów przygranicznych na zachodzie Ukrainy;

- uogólnienie w celu ustalenia korzyści płynących z kreowania destynacji i zastosowania podejścia klastrowego w obwodach przygranicznych na zachodzie Ukrainy;

- modelowanie rozwoju projektu klastra „Turystyczna Bukowina" (ukr. Туристична Буковина), który mógłby stać się podstawą do tworzenia regionów turystycznych oraz zapewnić zróżnicowany i innowacyjny rozwój turystyki w obszarach przygranicznych na zachodzie Ukrainy itp.

\section{WYNIKI BADAŃ}

Tworzenie destynacji turystycznych w obszarach przygranicznych powinno się opierać na: określeniu unikatowości oraz atrakcyjności naturalnych i ludzkich zasobów turystycznych; możliwości ich wykorzystania; analizie infrastruktury ogólnej oraz specjalistycznej, marketingu, doboru personelu i wsparcia finansowego, z uwzględnieniem doświadczeń innych krajów i zarządzania transgranicznego; a także na podejmowaniu właściwych decyzji dotyczących zarządzania.

Podkreślając znaczenie skutecznego zarządzania zasobami, Melnik stwierdza, iż:

Podstawą zarządzania zasobami społeczności lokalnej powinny być jasne wytyczne samorządów dotyczące podaży, wykorzystania oraz wydajności zasobów, oparte na współczesnych rodzajach podejścia naukowego, z uwzględnieniem potencjału zasobów. Powinno ono bazować na pewnych podstawowych zasadach, takich jak: substytucja importu, równowaga, wydajność, synergia, gospodarność, optymalizacja struktury, komplementarność, oraz stanowić podstawę właściwego mechanizmu zarządzania (Melnik, 2018, s. 18).

Autor proponuje także wykorzystanie mechanizmu zarządzania zasobami obszaru za pomocą złożonej macierzy wzajemnie powiązanych ze sobą elementów.

Odnośnie do tworzenia destynacji turystycznych w regionach przygranicznych na podstawie podejścia klastrowego oraz potrzeby tworzenia i wykorzystywania klastrów jako narzędzia zwiększania konkurencyjności produktów danej destynacji, można wyróżnić funkcje, cele i priorytety. „Z punktu widzenia branży turystycznej niejednorodność produktów turystycznych sprawia, że klastry turystyczne znacząco różnią się od klastrów w innych sektorach gospodarki. Innymi słowy, klastry turystyczne zawierają wiele uzupełniających się składników, należących nie tylko do sektora prywatnego, ale także do instytucji publicznych" (Yalçınkaya, Güzel, 2019, s. 28).

Przy założeniu, że destynacja turystyczna to obszar geograficzny, który ma określone granice oraz może przyciągać różne grupy turystów i zaspokajać ich potrzeby, utworzenie klastra turystycznego może pomóc $\mathrm{w}$ zjednoczeniu przedsiębiorstw i organizacji zaangażowanych w działalność turystyczną w obrębie społeczności lokalnej oraz skupieniu uwagi na średnich przedsiębiorstwach będących użytkownikami końcowymi.

Analiza doświadczeń innych krajów, a w szczególności badanie tworzenia i funkcjonowania klastrów w Rumunii i Polsce w regionach graniczących z południowymi i zachodnimi terenami Ukrainy, pokazuje dużą liczbę przedsiębiorstw i organizacji zjednoczonych w różny sposób i tworzących odmienne struktury. Na przykład do1 kwietnia 2020 r. w Departamencie Polityki Przemysłowej i Konkurencyjności Ministerstwa Gospodarki Rumunii zarejestrowano 76 inicjatyw klastrowych. Spośród nich 47 należy do stowarzyszenia klastrowego CLUSTERO, które jest organem przedstawicielskim rumuńskich klastrów i zrzesza łącznie ponad 2 tys. przedsiębiorstw oraz 189 tys. pracowników, 
a w 2020 r. osiągnęło obrót w wysokości 43,6 mld lei ${ }^{1}$ (Situatia clusterelor din Romania, 2020).

Odnośnie do tworzenia klastrów turystycznych, badanie ich rozwoju w Polsce potwierdza integrację organów działających w dziedzinie turystyki w powiązanych sektorach. Odgrywają one także ważną rolę w aktywizacji społeczności lokalnych oraz transformacji miejscowości lub ich dzielnic w obszary turystyczne, jak również w zwiększaniu ich konkurencyjności na rynku turystycznym (Roman, 2013).

Analiza czterech klastrów turystycznych, tj. Przemyskiego Klastra Turystycznego (Przemyśl - klaster turystyczny, 2016) i Małopolskiego Klastra Turystycznego (Kusa, Peszko, 2015) w Polsce oraz Karpackiego Klastra Turystycznego (Carpathian Tourism Cluster Romania, 2018) i Klastra Medycznego „Zdrowie Rumunii” (Clusterul Medical Sanatate Romania, 2019) w Rumunii, potwierdziła istnienie potrzeby opracowania podejścia, którego głównym zadaniem byłoby projektowanie krok po kroku klastra turystycznego oraz poszczególnych etapów kreowania destynacji turystycznych w przygranicznych obwodach zachodniej Ukrainy. Z tego badania wynika w szczególności, że podejście klastrowe do tworzenia miejsc wypoczynku w regionach przygranicznych dzieli się na następujące etapy:

1. Diagnostyczny, polegający na ocenie stanu ekologicznego, naturalnych zasobów rekreacyjnych, dziedzictwa kulturowego i historycznego, istniejącej infrastruktury turystycznej, dostępnych informacji, finansowania i doboru personelu, środowiska biznesowego, zainteresowania struktur rządowych, biznesowych oraz społecznych tworzeniem miejsc wypoczynku na podstawie podejścia klastrowego.

2. Analityczny, obejmujący analizę możliwości łączenia się w klastry przedsiębiorstw turystycznych $\mathrm{z}$ innymi firmami i organizacjami działającymi w regionie przygranicznym, badanie popytu na usługi turystyczne $\mathrm{w}$ danym miejscu oraz tworzenie ruchu turystycznego z regionów przygranicznych państw sąsiedzkich, organizację współpracy transgranicznej pomiędzy destynacjami turystycznymi oraz ocenę możliwych projektów i ich uczestników.

3. Przygotowawczy, podczas którego opracowywana jest koncepcja destynacji na podstawie podejścia klastrowego oraz niezbędnych systemów danych na potrzeby analizy właściwości oraz najważniejszych cech, warunków oraz czynników rozwoju regionów przygranicznych.

4. Organizacyjny i konstrukcyjny, uwzględniający tworzenie niezbędnych organów koordynujących, systemu środków i mechanizmów zarządzania, a także włączanie obszarów przygranicznych do euroregionów bądź innych organów o charakterze transgranicznym.

5. Strategiczny i prognostyczny, obejmujący rozwój strategii oraz prognozowanie wydajności funk- cjonowania destynacji, przedsiębiorstw i organizacji zjednoczonych w klaster, a także - w sensie ogólnym - rozwoju społecznego, gospodarczego i środowiskowego obszaru przygranicznego.

6. Kontrolno-naprawczy, pozwalający na poszukiwanie korelacji pomiędzy wstępnymi wynikami a ustalonymi celami, uogólnienie pozytywnych doświadczeń, jak również wprowadzenie zmian i modyfikacji.

Należy zauważyć, że opracowanie koncepcji miejsca docelowego na podstawie podejścia klastrowego powinno opierać się w całości na paradygmacie zrównoważonego rozwoju i jego strategiach, co oznacza, że wszystkie przedsiębiorstwa i organizacje danego klastra turystycznego muszą przystosować się do zmian poprzez modyfikację sposobu zarządzania, strategii marketingowych oraz innych programów funkcjonalnych.

Porównanie działalności uprzednio utworzonych klastrów turystycznych na Ukrainie - „Lvivske Opillya” (obwód lwowski) (Na Lvivshchyni zyavyvsya..., 2020) $\mathrm{i}$ „Kamyanets” (Kamieniec Podolski) (Turystychnyy klaster, 2020) - ze wspomnianymi klastrami turystycznymi w Polsce i Rumunii pomogło w sporządzeniu listy głównych struktur biznesowych, które mogą stać się częścią klastra i wziąć udział w tworzeniu destynacji turystycznej. Po pierwsze są to wiodący touroperatorzy, którzy wytwarzają i sprzedają usługi turystyczne, eksportując je poza granice regionu oraz kraju. Po drugie są to sieci przedsiębiorstw i organizacji, które produkują typowe usługi turystyczne oraz dostarczają je touroperatorom w regionie oraz turystom jako usługi dodatkowe. Po trzecie są to różne organizacje, które zapewniają kluczowym przedsiębiorstwom z branży turystycznej wykwalifikowany personel, zasoby finansowe, odpowiednią infrastrukturę itp.

Jednocześnie ustalono, iż głównym powodem, dla którego wymienione podmioty łączą się z innymi przedsiębiorstwami w klastry, są korzyści zarówno dla przedsiębiorstw, jak i dla destynacji, takie jak:

- rozszerzanie więzi, zakresu wzajemnej pomocy oraz współpracy pomiędzy wieloma niezależnymi organami, dzięki czemu uzyskuje się efekt synergii;

- zwiększenie wydajności środków trwałych oraz zdolności generowania i utrzymywania przewagi konkurencyjnej;

- tworzenie innowacyjnego środowiska, które wzmacnia konkurencyjność danych przedsiębiorstw w klastrze poprzez redukcję kosztów oraz optymalizację wartości produktów turystycznych w regionie docelowym;

- zmniejszenie stopnia ryzyka, zwiększenie jakości usług oraz polepszenie wizerunku obszaru turystycznego;

- zwiększenie atrakcyjności inwestycyjnej miejsca wypoczynku, efektywności zarządzania nim oraz działalności marketingowej poprzez tworzenie 
nowych marek, a także łączenie kapitału, wiedzy i umiejętności.

Dlatego podejście klastrowe $\mathrm{w}$ tworzeniu destynacji pomaga zjednoczyć organy zarówno współpracujące ze soba, jak i konkurujące w obrębie danej struktury organizacyjnej posiadającej wspólne cele, które muszą zostać spełnione w konkretnym miejscu i czasie.

Obwody przygraniczne na zachodzie Ukrainy, w tym: wołyński, zakarpacki, iwanofrankiwski, lwowski i czerniowiecki, graniczące z państwami Unii Europejskiej, charakteryzują się dużym potencjałem rozwoju wielu form turystyki. W szczególności są to obwody obfitujące w największe na Ukrainie zasoby wód mineralnych - znajduje się tam ponad 800 źródeł i ujęć wody, których całkowity dzienny przepływ wynosi $57500 \mathrm{~m}^{3}$. Do tej pory rezerwy operacyjne wód mineralnych o właściwościach terapeutycznych zostały zatwierdzone wyłącznie w 13 miejscach, w objętości 4600 m³/dzień (Mazur, 2005). Potencjał naturalny i rekreacyjny (RDP) wymienionych obwodów stanowi 19,6\% całkowitego RDP Ukrainy (Rudenko i in., 2019). W tabeli 1 przedstawiono dane dotyczące rozkładania się RDP na obszarach wzdłuż zachodnich granic Ukrainy.

Jak widać w tabeli 1, najwyższe wartości RDP odnotowano w okręgach zakarpackim i lwowskim (odpowiednio $43 \%$ i 30\%) w odniesieniu do zasobów w postaci zabiegów sanatoryjnych, które są znaczącym czynnikiem wpływającym na tworzenie destynacji związanych z rekreacją i zdrowiem. Sytuacja przedstawia się jeszcze lepiej w obwodach przygranicznych na zachodzie Ukrainy, które moga poszczycić się dziedzictwem kulturowym i historycznym (tab. 2). W tych obwodach znajdują się aż cztery z siedmiu ukraińskich obiektów wpisanych na listę światowego dziedzictwa ludzkości UNESCO. W odniesieniu do dziedzictwa kulturowego i historycznego o randze ogólnokrajowej Polyvach zauważa, że „Rozmieszczenie miejsc dziedzictwa kulturowego o znaczeniu ogólnonarodowym w poszczególnych jednostkach podziału administracyjnego jest nierównomierne. Obwody z największą liczbą zabytków w przeliczeniu na $1000 \mathrm{~km}^{2}$ to: lwowski, iwanofrankiwski, zakarpacki, tarnopolski, chmielnicki, czerniowiecki, wołyński, miasta Kijów i Sewastopol" (Polyvach, 2012, s. 97).

Dane zaprezentowane w tabeli 2 pokazują, że w samym obwodzie lwowskim znajduje się ok. 20\% zabytków o znaczeniu ogólnokrajowym według wszystkich ukraińskich wskaźników, a łącznie w obwodach przygranicznych na zachodzie Ukrainy tego typu zabytki stanowią 35,8\% wszystkich zlokalizowanych w miejscach wypoczynku na poziomie regionalnym.

Wyniki badań ankietowych przeprowadzonych w okresie od października do grudnia 2019 r. wśród

Tabela 1. Potencjał naturalny i rekreacyjny obwodów zachodniej Ukrainy

\begin{tabular}{|l|c|c|c|}
\hline \multirow{2}{*}{$\begin{array}{l}\text { Obwody przygraniczne } \\
\text { na zachodzie Ukrainy }\end{array}$} & \multicolumn{3}{|c|}{ Potencjał naturalno-rekreacyjny } \\
\cline { 2 - 4 } & \multirow{2}{*}{$\begin{array}{c}\text { Udział w całkowitym } \\
\text { PNR Ukrainy }(\mathrm{w} \%)\end{array}$} & Zasoby rekreacyjne i turystyczne & Zasoby w postaci zabiegów sanatoryjnych \\
\hline Zakarpacki & 1,557 & 80 & 20 \\
\hline Lwowski & 7,036 & 57 & 43 \\
\hline Iwanofrankiwski & 3,929 & 84 & 16 \\
\hline Czerniowiecki & 5,377 & 70 & 30 \\
\hline Wołyński & 1,744 & 79 & 21 \\
\hline Łącznie & 19,6 & 74 & 26 \\
\hline
\end{tabular}

Źródło: Rudenko i in. (2019, s. 198).

Tabela 2. Dziedzictwo kulturowe i historyczne o znaczeniu ogólnokrajowym w obwodach przygranicznych na zachodzie Ukrainy

\begin{tabular}{|l|c|c|c|c|c|c|}
\hline \multirow{2}{*}{$\begin{array}{c}\text { Obwody przygraniczne } \\
\text { na zachodzie Ukrainy }\end{array}$} & \multirow{2}{*}{$\begin{array}{c}\text { Liczba atrakcji } \\
\text { ogółem }\end{array}$} & $\begin{array}{c}\text { Z tybytki } \\
\text { historyczne }\end{array}$ & $\begin{array}{c}\text { zabytki } \\
\text { sztuki }\end{array}$ & $\begin{array}{c}\text { zabytki } \\
\text { archeologiczne }\end{array}$ & $\begin{array}{c}\text { zabytki } \\
\text { architektury }\end{array}$ & łacznie \\
\hline Lwowski & 1961 & 7 & 1 & 16 & 200 & 224 \\
\hline Iwanofrankiwski & 2051 & 0 & 2 & 11 & 137 & 150 \\
\hline Czerniowiecki & 3947 & 2 & 1 & 10 & 149 & 162 \\
\hline Zakarpacki & 8441 & 7 & 1 & 14 & 794 & 816 \\
\hline Wołyński & 2246 & 2 & 0 & 18 & 112 & 132 \\
\hline Łącznie w obwodach przygranicznych Ukrainy & 18646 & 18 & 5 & 69 & 1392 & 1484 \\
\hline Łącznie na Ukrainie & 131293 & 142 & 44 & 418 & 3541 & 4145 \\
\hline
\end{tabular}

Źródło: Polyvach (2012, s. 97). 
menedżerów 140 firm turystycznych oraz firm powiązanych w obwodach przygranicznych na zachodzie Ukrainy, gdzie można kreować destynacje turystyczne, dają podstawy do twierdzenia, że zainteresowanie tworzeniem klastrów turystycznych jest bardzo duże. Zgodnie z wynikami ankiety spośród 632 menedżerów firm turystycznych oraz firm powiązanych aż 427 wsparłoby działania klastrów turystycznych, inkubatorów biznesu oraz innych organów regionalnych. Z kolei 115 menedżerów uważa współpracę z takimi stowarzyszeniami za mniej korzystną ze względu na fakt, że ograniczają one działalność poszczególnych przedsiębiorstw. Pozostali ankietowani wskazali na konieczność doprecyzowania korzyści płynących ze współpracy w ramach klastra.

Wielu naukowców postrzega tworzenie i rozwój miejsc wypoczynku wyłącznie przez pryzmat ich wpływu na kondycję gospodarczą obszaru, w którym zostały ustanowione. W przypadku destynacji regionalnych chodzi w szczególności o wzrost wartości produktu regionalnego brutto, który przekłada się na zwiększenie dochodów, tworzenie nowych miejsc pracy, budowanie infrastruktury oraz inne podobne zmienne. Jednocześnie doświadczenia innych krajów oraz wyniki badań autorów niniejszej pracy potwierdzaja, że efektywne funkcjonowanie obszarów docelowych poza poprawą wskaźników ekonomicznych skutkuje wydłużeniem średniej długości życia, zmniejszeniem wskaźnika przestępczości, polepszeniem usług edukacyjnych, zdrowotnych, kulturalnych, sportowych i innych.

Dlatego też klastrów turystycznych nie powinno się tworzyć wyłącznie na bazie przedsiębiorstw oferujących usługi dla odwiedzających, turystów i mieszkańców, jak np.: hotele, gastronomia, transport, firmy turystyczne i wycieczkowe, wytwórcy pamiątek i inne organy, wraz z osobami fizycznymi zaangażowanymi w produkcje i dystrybucję typowych usług zlokalizowanych w danym regionie docelowym. Także inne przedsiębiorstwa i organizacje, władze lokalne i krajowe, instytucje edukacyjne, medyczne, kulturalne, sportowe, media, służby porządkowe, stowarzyszenia publiczne i pozostałe podmioty, które nie są bezpośrednio powiązane z turystyka, powinny zostać w pełni zaangażowane. Podejście to jest wyraźnie odmienne od dotychczasowych koncepcji klastrów turystycznych, które - zdaniem autorów - mają ograniczone możliwości.

Wstępna koncepcja rozwoju turystyki w obwodzie czerniowieckim (Bukowina) i roboczy model klastra

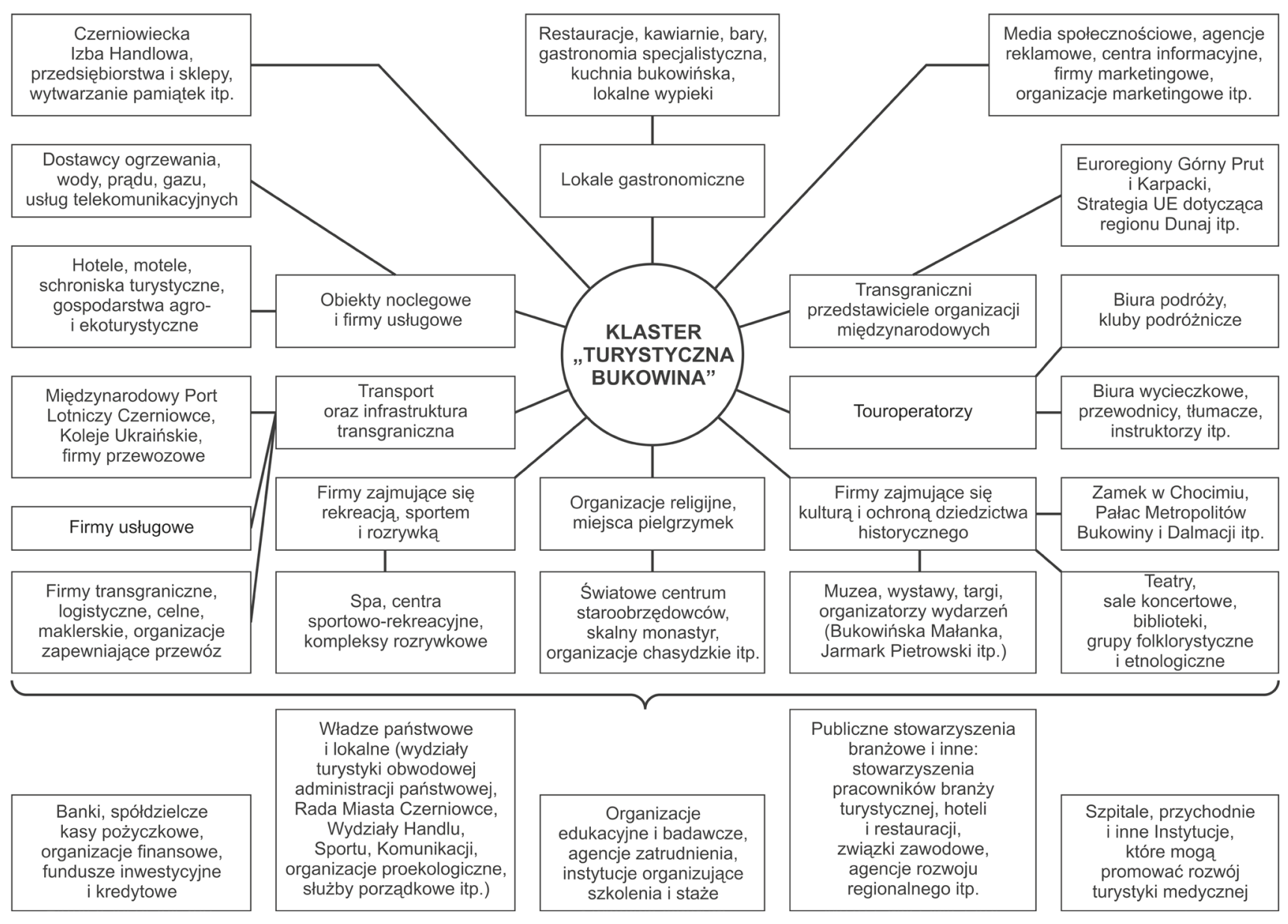

Rysunek 1. Projekt modelu klastra „Turystyczna Bukowina” Źródło: opracowanie własne 
„Turystyczna Bukowina” będą stanowić bazę do stworzenia destynacji turystycznej, zapewniającej różnorodny oraz innowacyjny charakter rozwoju turystyki $\mathrm{w}$ regionie przygranicznym na południowym zachodzie Ukrainy.

Administracja Państwowa Obwodu Czerniowieckiego wyróżniła sześć „magnesów turystycznych” (Chernivets'ka ODA vyznachyla, 2020). Stanowią je:

- historyczne centrum Czerniowców z wpisanym na listę światowego dziedzictwa UNESCO Pałacem Metropolitów Bukowiny i Dalmacji (Residence of Bukovinian and Dalmatian Metropolitans, 2011);

- Czerniowieckie Regionalne Muzeum Ludoznawcze;

- zamek w Chocimiu;

- stacja radarowa Pamir;

- skalny monastyr św. Mikołaja we wsi Galicja (ukr. Галиия);

- światowe centrum staroobrzędowców we wsi Biała Krynica (ukr. Біла Криниця).

Te oraz inne miejsca turystyczne w obwodzie czerniowieckim są znane na całym świecie jako pomniki kultury, architektury i historii oraz cele pielgrzymek religijnych, cieszące się ogromnym zainteresowaniem zarówno wśród Ukraińców, jak i turystów zagranicznych. Każde $\mathrm{z}$ nich jest usytuowane w innym rejonie, wspólnie zaś pokrywają praktycznie całe terytorium obwodu, co uzasadnia utworzenie regionalnej destynacji turystycznej i klastra „Turystyczna Bukowina”.

Celem ogólnym klastra „Turystyczna Bukowina” jest zagwarantowanie utworzenia innowacyjnego miejsca wypoczynku, które przyczyni się do rozwoju społeczno-gospodarczego całego regionu. Model omawianego projektu klastra został przedstawiony na rys. 1.

Przedstawiony na rys. 1 model klastra „Turystyczna Bukowina" pozwala na skoncentrowanie w obwodzie czerniowieckim jako destynacji turystycznej wielu wzajemnie powiązanych przedsiębiorstw i organizacji zajmujących się projektowaniem, rozwijaniem, promocja, sprzedażą i świadczeniem typowych usług turystycznych. Stowarzyszenie organizacji ponadgranicznych, przedsiębiorstwa zajmujące się infrastrukturą transgraniczna, władze lokalne i krajowe, inne firmy oraz struktury społeczne mogą wspierać branżę turystyczną. Cechą szczególną niniejszego podejścia do tworzenia regionów docelowych jest fakt, że obejmuje ono cele transgraniczne, w których osiąganiu obwód czerniowiecki odgrywa ważną rolę.

\section{WNIOSKI I POSTULATY DALSZYCH BADAŃ}

Na podstawie wyników przeprowadzonych badań można wyciągnąć pewne wnioski. Podejście klastrowe do tworzenia destynacji turystycznych $\mathrm{w}$ regionach przygranicznych na zachodzie Ukrainy, w których są unikatowe zasoby turystyczne, zależy w dużej mierze od cech danej lokalizacji, sprzyjających powstawaniu korzystnych warunków do rozwoju turystyki, jak i narzucających pewne ograniczenia we wdrażaniu inicjatyw klastrowych. Dlatego też na etapie planowania i tworzenia klastrów oraz formowania destynacji turystycznych o szczególnym znaczeniu od decyzji władz obwodowych, które są świadome mocnych i słabych stron danego miejsca, zależy tworzenie atrakcyjnych warunków dla turystyki i rekreacji na podstawie lokalnych zasobów turystycznych, dostępnej infrastruktury, możliwości ruchu turystycznego, zasobów finansowych i kadrowych itp.

Podejście klastrowe do destynacji turystycznych oraz zaproponowany model klastra będą sprzyjać rozwojowi takich procesów w regionalnych gospodarkach, jak: - unifikacja struktur biznesowych, rządowych i publicznych; instytucje naukowe, edukacyjne, kulturalne, sportowe i inne zagwarantują zróżnicowany i innowacyjny charakter rozwoju turystyki w regionach przygranicznych na zachodzie Ukrainy;

- wzrost liczby turystów, rozszerzenie oferty usług turystycznych i zwiększenie tempa regionalnego wzrostu gospodarczego;

- wzrost konkurencyjności produktów turystycznych i jakości usług w tej branży;

- wzrost wielkości eksportu usług turystycznych do regionów przygranicznych krajów sąsiedzkich oraz poprawa jakościowa struktur;

- wzrost atrakcyjności inwestycyjnej regionów na zachodzie Ukrainy oraz rozwój ogólnej i specjalistycznej infrastruktury granicznej;

- rozwój kultury, sportu, nauki oraz poprawa jakości edukacji;

- tworzenie środowiska biznesowego ukierunkowanego na innowacje.

Podejście klastrowe do tworzenia destynacji turystycznych to kompleksowe podejście do możliwości danego regionu, które pozwala na efektywne wykorzystanie potencjału zasobowego oraz tendencji w rozwoju turystyki.

Gdy mowa o perspektywach dalszego rozwoju, duże znaczenie miałoby ustalenie zasad tworzenia destynacji na podstawie podejścia klastrowego, analizy SWOT jako metody oceny czynników wewnętrznych i zewnętrznych, analizy PEST zastosowanej w celu identyfikacji aspektów politycznych, gospodarczych, społecznych oraz technicznych. Ważnym aspektem kontynuacji tego rodzaju studiów jest również przeprowadzenie badań nad wpływem epidemii koronawirusa na procesy integracji w klastrach turystycznych.

\section{PRZYPIS}

${ }^{1}$ 10,16 biliona dolarów, stan na 13 czerwca 2020 r. 


\section{BIBLIOGRAFIA}

Algieri, B., Aquino, A., Succurro, M. (2018). International competitive advantages in tourism: An eclectic view. Tourism Management Perspectives, 25, 41-52. https://doi.org/10.1016/j. tmp.2017.11.003

Bellini, N., Grillo, F., Lazzeri, G., Pasquinelli, C. (2017). Tourism and regional economic resilience from a policy perspective: Lessons from smart specialization strategies in Europe. Journal European Planning Studies, 25 (1), 140-153. https://doi.org/10.1 080/09654313.2016.1273323

Beltramo, R., Rostagno, A., Bonadonna, A. (2018). Land consolidation associations and the management of territories in harsh Italian environments: A review. Resources, 7. Pobrane $\mathrm{z}$ : https://www.mdpi.com/2079-9276/7/1/19 (15.07.2020). https:// doi.org/10.3390/resources7010019

Benner, M. (2017). From clusters to smart specialization: Tourism in institution-sensitive regional development policies. Economies, 5 (3), 26. https://doi.org/10.3390/economies5030026

Bobrovska, O.Y., Krushelnytska, T.A., Latinin, M.A., Lypovska, N.A., Dreshpak, V.M. (2017). Potentsial rozoytku terytoriy: metodolohichni zasady formuvannya i naroshchennya [Potential of territorial development: methodological principles of formation and increase]. Dnipro: DRIDU NADU [w jęz. ukr.].

Carpathian Tourism Cluster Romania (2020). Tourism-clusterromania.com. Pobrane z: http://tourism-cluster-romania.com/ tourism-region/carpathian-mountains (23.07.2020).

Chernivets'ka ODA vyznachyla shist' «turystychnykh mahnitiv» Bukovyny [Chernivtsi Regional State Administration has identified six "tourism magnets" of Bukovina] (2020). Molbuk.ua. Pobrane z: https://molbuk.ua/chernovtsy_news/202752-chernivecka-oda-vyznachyla-6-turystychnykh-magnitiv-bukovyny.html (12.08.2020).

Clusterul Medical Sanatate Romania [Romania Health Medical Cluster] (2020). Sanatateromania.ro. Pobrane z: https://www.sanatateromania.ro/prezentare [w jęz. rum.] (23.07.2020).

Gerasymenko, V. (red.) (2016). Otsinka turystychno-rekreatsiynoho potentsialu rehionu [Assessment of tourism and recreational potential of the region]. Odessa: ONEU [w jęz. ukr.].

Korzh, N.V., Basyuk D.I. (2017). Upravlinnya turystychnymy destynatsiyamy [Management of tourism destinations]. Winnica: «PP «TD Edel'veys i K» [w jęz. ukr.].

Kravtsiv, V.S. (ed.). (2015). Rozvytok transkordonnoho spivrobitnytstva: naukovo-analitychna dopovid' [Development of cross-border cooperation: academic and analytical report]. Lwów: DU «Instytut rehional'nykh doslidzhen' imeni M.I. Dolishn'oho NAN Ukrayiny» [w jęz. ukr.].

Kusa, R., Peszko, A. (2020). Małopolski klaster turystyczny - perspektywy rozwoju w świetle badań własnych. Zarz.agh.edu.pl. Pobrane z: http://www.zarz.agh.edu.pl/rKusa/ZZ_P19_06'\%20 MalopolskiKlasterTurystyczny.pdf (13.06.2020).

Mazaraki, A.A. (red.) (2019). Ukraine and the world: The tourism system. Praga: Eatern European Center of the Fundamental Researchers (EECFR).

Mazur, F. (2005). Sotsial'no-ekonomichni umovy rozvytku rekreatsiynoyi industriyi (na prykladi Karpat.s'koho rehionu) [Socio-economic conditions for the development of the recreational industry (on the example of the Carpathian region)]. Kijów: Tsentr Uchbovoyi Literatury [w jęz. ukr.].

Melnik, A.F. (2018). Upravlinnya resursamy terytoriyi v konteksti yevropeys'koyi ta natsional'noyi polityky rehional'noho rozvytku [Territory resource management in the context of European and national regional development policy]. Visnyk Ternopil's'koho natsional'noho ekonomichnoho universytetu - The Herald of Ternopil National Economic University, 3, 7-22 [w jęz. ukr.]. https://doi.org/10.35774/visnyk2018.03.007
Mikula, N., Matvyeyev, Y., Tymechko, I. (2014) Specific features of organization of new cross-border cooperation forms. W: R. Fedan, B. Petrecka, S. Dyrda-Maciałek (red.), Problemy współczesnej Europy-ujecie interdyscyplinarne (s. 31-38). Jarosław: Wydawnictwo Państwowej Wyższej Szkoły Techniczno-Ekonomicznej im. ks. Bronisława Markiewicza.

Na Lvivshchyni zyavyvsya novyy turystychnyy klaster «Lvivske Opillya» [A new tourism cluster "Lvivske Opillya" has appeared in Lviv region] (2020). Decentralization.gov.ua. Pobrane z: https:// decentralization.gov.ua/news/12162 (14.09.2020).

Naumanen, M. (2019). European panorama of clusters and industrial change: Emerging industries: Driving strength in 10 cross-sectoral industries. European Commission EC. Pobrane z: https://cris. vtt.fi/en/publications/european-panorama-of-clusters-and-industrial-change-emerging-indu (20.01.2021).

Novelli, M., Schmitz, B., Spencer, T. (2006). Networks, clusters and innovation in tourism: A UK experience. Tourism Management, 27, 1141-1152. https://doi.org/10.1016/j.tourman.2005.11.011

Odinokova, T. (2019). Tourism cluster as a form of innovation activity. Economics. Ecology. Socium, 3 (2), 1-11. https://doi. org/10.31520/2616-7107/2019.3.2-1

Oteshova, A.K., Niyazbayeva, A.A., Prodanova, N.A., Patuti na, N.A., Moshkin, A.S., Sabirova, R.K. (2020). Investment bases for the development of clusters at the regional level. Talent, Development \& Excellence, 12 (2), 768-775.

Polyvach, K.A. (2012). Kul'turna spadshchyna ta yiyi vplyv na rozvytok rehioniv Ukrayiny [Cultural heritage and its influence on the development of regions of Ukraine]. Kijów: Institute of Geography, NAS of Ukraine [w jęz. ukr.].

Porter, M. (2005). Konkurentsyya [Competition]. Moskwa: Izdatel'skiy dom «Vil'yams» [w jęz. ros.].

Porter, M. (2016). Konkurentnaya strategiya: Metodika analiza otrasley $i$ konkurentov [Competitive strategy: a methodology for analyzing industries and competitors]. Moskwa: Alpina Publisher [w jęz. ros.].

Przemyśl - klaster turystyczny [Przemyśl - tourism cluster] (2020). Miasta.pl. Pobrane z: http://www.miasta.pl/aktualnosci/przemysl-klaster-turystyczny (22.10.2020).

Residence of Bukovinian and Dalmatian Metropolitans (2020). Whc. unesco.org. Pobrane z: http://whc.unesco.org/en/list/1330 (4.09.2020).

Roman, M. (2013). Klastry jako forma współdziałania w działalności turystycznej. Zarządzanie i Finanse, 1 (3), 309-320.

Rudenko, V.P., Rudenko, S.V., Pidhirna, V.N., Tsependa, M.V., Yachnyuk, M.O., Vatseba, V.Y., Danilova, O.M., Hrytsku, V.S., Tsependa, M.M.,Palamaryuk, M.Y., Chubrey, O.S., Yemchak, T.V., Rybchuk, Y.O., Kibych, I.V., Nakonechnyy, K.P., Burka, V.Y. (2019). Menedzhment turystychnoyi industriyi [Management of the tourism industry]. Czerniowce: CHNU: Ruta [w jęz. ukr.].

Situatia clusterelor din Romania. Rezumat. Aprilie 2020 [Cluster situation in Romania. Summary. April 2020] (2020). Clustero.eu. Pobrane z: http://clustero.eu/wp-content/ uploads/2020/04/ situatia-clusterelor-din-romania-aprilie-2020.pdf [w jęz. rum.] (29.08.2020).

Stasiak, A. (2007). Klaster turystyczny - nowe wyzwanie dla ROT-ów i LOT-ów? Rocznik Naukowy Wyższej Szkoły Turystyki $i$ Rekreacji im. M. Orłowicza w Warszawie, 6, 183-196.

Turystychnyy klaster «Kamyanets'» [Kamyanets tourism cluster] (2020). Clarity-project.info. Pobrane z: https://clarity-project. info/edr/26514268 (13.09.2020).

Varnalius, Z.S. (red.). (2005). Rehiony Ukrayiny: Problemy ta priorytety sotsial'no-ekonomichnoho rozoytku [Regions of Ukraine: problems and priorities of socio-economic development]. Kijów: Znannya Ukrainy [w jęz. ukr.].

Yalçınkaya, T., Güzel, T. (2019). A general overview of tourism clusters. Journal of Tourism Theory and Research, 5 (1), 28-39. https://doi.org/10.24288/jttr.465912 